\title{
Educational diversity, organizational structure and innovation performance: Evidence from Uruguayan industry
}

Diversidad educativa, estructura organizacional y desempeño innovador: Evidencia de la industria uruguaya

\author{
Alejandro Bello-Pintado* \\ CARLOS BIANCHI**
}

\begin{abstract}
This paper analyses the relationship between horizontal educational diversity (HED) and firm innovation performance, both in the propensity to innovate and the intensity of innovation in firm performance. Moreover, we hypothesise that the organizational structure of the firm moderates this relationship. Using panel data from the Uruguayan Innovation Survey 2006-2012, econometric estimates show that HED is barely associated with innovation performance in products and processes. We found that advanced organisational structures of the firm positively moderate the former relationship, but only for firms achieving radical innovations.
\end{abstract}

Key words: Educational diversity, organizational structure, innovation performance, Uruguay.

JEL Classification: O32, M14, L60.

Acknowledgements: The suggestions and criticism by anonymous referees were immensely constructive and helpful, we sincerely thank him. All remaining errors are ours. We acknowledge the collaboration of the Agencia Nacional de Investigación e Innovación, Uruguay, which provided access to UIS microdata. We also acknowledge the financial support of the Spanish Ministry of Education and Science (ECO2013-48496-C04-12-R).

* Public University of Navarre -Campus Arrosadía, s/n, Navarre, Spain. E-mail: alejandro. bello@unavarra.es

** Universidad de la República, Facultad de Ciencias Económicas, Instituto de Economía, Uruguay. E-mail: cbianchi@iecon.ccee.edu.uy (corresponding author).

Received: 17 de octubre de 2017. Accepted: 24 de mayo de 2018. 


\section{Resumen}

Se analiza la relación entre la diversidad educativa horizontal (DEH) y el desempeño innovador de las empresas, considerando el efecto de la DEH tanto en la propensión a innovar como en la intensidad innovadora de la empresa. Asimismo, se contrasta la hipótesis de que la estructura organizativa de la empresa modera dicha relación. Se usan datos de panel de la Encuesta de Actividades de Innovación de Uruguay entre 2006 y 2012. La DEH tiene escasa asociación con el desempeño innovador de la empresa. Las formas avanzadas de organización de la empresa tienen un efecto moderador positivo en dicha relación solo cuando se trata de empresas que alcanzan innovaciones radicales.

Palabras clave: Diversidad educativa, estructura organizacional, desempeño innovador, Uruguay.

Clasificación JEL: O32, M14, L60.

Reconocimientos: Las críticas y sugerencias del revisor anónimo fueron sumamente constructivas y nos ayudaron a mejorar el trabajo, sinceramente le agradecemos por su ayuda. Cualquier error que perdurase es de nuestra exclusiva responsabilidad. Queremos agradecer la colaboración de la Agencia Nacional de Investigación e Innovación (ANII) de Uruguay, quien permitió el acceso a los microdatos de la Encuesta de Actividades de Innovación. Agradecemos también el apoyo financiero del Ministerio de Educación y Ciencia de España (ECO2013-48496-C04-12-R).

\section{INTRODUCTION}

In recent years, the study of workforce diversity and its implications for the economics and management of organisations has been a topic of great debate and on-going discussion (Choi et al., 2016). Race, gender, age, sexual orientation, national origin, tenure, and educational and functional backgrounds have been the dimensions of workforce diversity most studied in social sciences (Laursen et al., 2006; Shore et al., 2009; Bell et al., 2011; Díaz-García et al., 2013). In particular, the literature on innovation is focusing much effort on the study of workforce diversity as a determinant of innovation outcomes (Östergaård et al., 2011; Díaz-García et al., 2013; Parrotta et al., 2014; Pfeifer and Wagner, 2014; Garcia-Martinez et al., 2017; Bolli et al., 2018). A positive correlation between workforce diversity and innovation outcomes is often expected since diversity might broaden the innovation search space of the firm and improve the firm's capacities to recognise and use new ideas through the interaction between different types of competencies and knowledge (Östergaård et al., 2011). However, diversity is also a challenge for firms since it might also lead to conflict, distrust and negative effects for out-group members (Shore et al., 2009; Li, 2014).

The relationship between firm innovation and educational workforce diversity shows some specific features. In particular, this is because the formal educational 
background of the workforce is one of the main indicators of a firm's internal capabilities. It may be the most important source of knowledge and expertise in firms (Pelled, 1996; Dahlin et al., 2005) and it is a determinant of innovation behaviour (Schneider et al., 2010; De Winne and Sels, 2010; D'Este et al., 2014).

This paper aims to contribute to this research topic, by analysing the relationship between HED and innovation performance in Uruguay. This case is one of a small medium-income country that has built an incipient innovation system, but which still has critical weaknesses, mainly related to major scale constraints (Aboal et al., 2014) and system coordination (Berrutti and Bianchi, 2017).

Firms in small developing contexts face specific challenges related to conducting innovation paths which involve a highly qualified workforce. First, there is a challenge related to the rigidities of the professional workforce supply. Firms face the challenge of attracting and retaining highly qualified workers. Second, the value of educational diversity is related to the value of knowledge variety as a critical input in innovation processes. In less developed contexts, characterised by a relatively undiversified production structure and low average innovation, the demand for knowledge from productive activities is usually limited (Arocena and Sutz, 2010; Pagés, 2010). Hence, this paper aims to contribute to the understanding of the specific features of the relationship between educational diversity and innovation performance in small developing countries, which have been barely studied (Ruiz-Mejías and Corrales-Mejías, 2015a and 2015b).

Workforce diversity and innovation have a complex and controversial relationship (Yang and Konrad, 2011). This is because the development of effective working relationships is more complex in diverse workplaces than in homogeneous ones (van Knippenberg et al., 2004). Hence, a question for further attention is the potential curvilinear relationship between workforce diversity and performance outcomes (Horwitz and Horwitz, 2007). According to Katz and Du Preez (2008), a varied knowledge base can generate many new promising ideas but may fail in the midst of implementation because they lack sufficient depth of knowledge to transform it into a radical innovation (Zahra and George, 2002). Furthermore, conflict associated with different views may increase with the diversity in education (e.g. number of different categories of professionals). However, according to these views, this type of relationship would only be observed among firms with relatively high diversity. Even though it is hardly the situation of firms in small developing countries, we checked for the existence of an inverted U-shape in the relationship between HED and innovation performance in Uruguay.

On the other hand, researchers have suggested that favourable outcomes from workforce diversity are conditioned by the organisational structure of the firm, which ultimately determines how people interact in the decision making process (Harrison and Klein, 2007; Bresman and Zellmer-Bruhn, 2013). In this vein, Faems and Subramanian (2013) make a call to consider how the workforce is structured and managed to analyse the impact of educational diversity in innovation outcomes. Li (2014) highlights the need to establish a governance mechanism to manage the potential impact of team diversity. In addition, 
García-Martinez et al. (2017) highlight organizational capabilities to leverage diversity as strategic resources to foster innovation and creativity. As a result, in this paper we consider that the organizational structure of the firm moderates the relationship between HED and innovation performance.

The relationships between workforce educational diversity and innovation performance have gained attention among innovation studies. Many studies have analysed the relationship between vertical educational diversity of the firm workforce (Bolli et al., 2018; Subramanian et al., 2016; Parrotta et al., 2014; Garcia-Martinez et al. (2017) by differentiating the workforce composition by educational attainment. Other recent works have studied the effects of HED on innovation performance (Östergaård et al., 2011; Dahlin et al., 2005) by analysing the effects of educational background variety as a proxy of knowledge variety of firms. This paper follows the last approach, and aims to contribute to understanding of the specific features of the relationship between HED and innovation performance in a small developing country.

The next section presents a brief theoretical review of the economics of the firm (resource based view) and social analysis (social identities) to summarize the main arguments on the positive and negative effects of workforce diversity on innovation performance. These arguments are discussed in light of empirical evidence from previous research. Moreover, in this section we elaborate on the expected moderating effect of the organizational structure of the firm on the relationship between HED and innovation performance. The third section presents the stylised features of the Uruguayan innovation system and the research hypotheses. The following section presents the empirical strategy. Section five discusses the main results of the econometric exercise and, finally, the main conclusions are presented in section six.

\section{Literature REVIEW}

\subsection{Workforce diversity and innovation performance}

The understanding of the expected relationship between educational diversity and innovation performance in less developed contexts is supported by several complementary theories.

The resource-based view (RBV) theory posits that internal firm resources are determinants of firms' competitive advantage (Wernerfelt, 1984). Specifically, the knowledge-based view (KBV) theory of the firm considers knowledge as the most important resource of a firm (Grant, 1996). Knowledge-based resources are usually difficult to imitate. According to this theory, educational diversity increases the knowledge base of the firm, which in turn contributes to developing distinctive capabilities; for instance, identifying and exploiting new and different sources of information (Zahra and George, 2002) or broadening viewpoints (Berliant and Fujita, 2011). Highly qualified workers with different professional profiles have a broader variety of techniques and methods to tackle a particular 
technological challenge, improving the likelihood of success in innovation (Baldwin and Clark, 2000). For example, diversity of in-group composition in terms of skills, information use and knowledge encourages firms to engage in innovation activities and may contribute to achieving innovation results in terms of new products and processes (Cohen and Levinthal, 1990; Östergaård et al., 2011). This fact is particularly important in small developing countries where professionals and highly qualified workers are one of the more relevant sources of information and knowledge (Sutz, 2012; Bianchi et al., 2011).

Early studies focusing on KBV affirm that the breadth of the knowledge base positively affects innovation (De Carolis and Deeds, 1999). Moreover, more recent investigations assert that a firm's knowledge base is its most unique resource for radical innovation (Zhou and Li, 2012).

However, the relationship between workforce diversity and firm performance is complex and gradual, with different forms depending on the degree of diversity degree and the specific case under study.

From the social identity approach, diversity can be contrary to the effectiveness of a group since more similar individuals are assumed to be more effective when working together. As a result, workers' social identities not being aligned might cause conflict, unproductive forms of competitive behaviour, and less cooperation and communication than in homogeneous groups (Schneider and Northcraft, 1999). In such a context, communication and coordination costs are likely to be higher to manage the diverse education of qualified workers (Dahlin et al., 2005). Contrary to this view, it has been stated that the more interpersonal congruence in a group, the more the group is open to experience. This allows members to achieve harmonious and effective work processes by expressing rather than suppressing the attributes that make them unique (Ely and Thomas, 2001).

Empirical works have analysed the impact of workforce educational diversity on different measures of innovation performance (e.g. number of patents achieved, radical and incremental innovations), but without showing conclusive results. Bantel and Jackson (1989) analysed the relationship between the characteristics of the top management team and innovation in banking and found that more educated and varied teams managed the more innovative banks. Dahlin et al. (2005) showed that team vertical educational diversity (diversity in educational level or attainment) provides information processing benefits that outweigh limitations associated with social categorisation processes to achieve innovation performance. García-Martínez et al. (2017) found a positive association between workforce educational diversity and both radical and incremental innovation. Along these lines, Bolli et al. (2018) found that vertical educational diversity increases the extensive margin of $\mathrm{R} \& \mathrm{D}$ and new product innovation.

Contrary to these findings, based on the social categorization perspective and the information/decision-making perspective, Faems and Subramanian (2013) found that informational benefits from educational diversity do not have statistically significant relationships with patent applications. Similarly, Parrotta et al. (2014) found a weak association between diversity in education and patent applications in Denmark. 
Related evidence from Latin America is practically non-existent. Firms in Latin American countries are typically engaged in innovation through the acquisition of knowledge embedded in capital goods (Goedhuys and Veugelers, 2012). In the same vein, Pagés (2010) found a dominance of adaptation and incremental innovations rather than radical innovations in Latin American countries. It has been stated that firms with a large number of highly skilled workers are able to differentiate through new developments or through the intensive exploitation of innovations incorporated into goods and services (Duryea et al., 2008). Evidence from Brazil indicates that product innovation appears to be more intensive in its use of highly skilled (secondary and post-secondary qualified) workers, raising the probability of being a product innovator, while process innovators demand fewer workers with high skill levels (Goedhuys and Veugelers, 2012).

In sum, economic and social theories offer arguments in favour, and some against, the positive association between educational diversity and innovation performance. Empirical evidence shows that the benefits of educational diversity, associated with new knowledge generation, outweigh the high cost of coordination and communication arising workforce diversity management. Coordination costs associated with highly skilled workers are low in less developed contexts, largely due to the fact that there are simply fewer of such workers in the labour supply of the economy (Pagés, 2010). In addition, the empirical evidence observed in developed contexts is expected to also be observed in a small developing country.

\subsection{The role of firm organizational structure}

The relevance of management practices, their effects on the organizational structure of firms and their effects on firm performance have been widely highlighted in economics and management research (Bloom and Van Reenen, 2010; Black and Lynch, 2004).

Based on this literature, we point out that the relationship between HED and innovation performance can be moderated by the structure of the organization and the way work is routinely organised (Sapprasert and Clausen, 2012). More advanced organizational structures (explicitly defined for purposes of the present paper in section 4.3 ) promote the interaction of employees with different profiles, reduce vertical differentiation among hierarchies and usually organize people in inter-functional groups (Leiponen, 2005). These structures favour the development of new ideas or complex problem solving processes, which are usually associated with the decision to engage in innovation activities and in particular the internal development of them (Bresman and Zellmer-Bruhn, 2013).

Empirical evidence on educational diversity as pertains to organizational and innovation performance suggests that favourable outcomes from diversity are conditioned by whether employees participate in the decision making process (Harrison and Klein, 2007). The development of effective working relationships is more difficult in diverse workplaces than in homogeneous ones (van Knippenberg et al., 2004). Moreover, advanced organizational structures allow 
various professional backgrounds to be effectively deployed, by promoting routines which are amenable to building technological innovation capacity (Camisón and Forés, 2010).

Regarding the context under study, Latin American countries show some peculiarities that condition the way firms are managed (e.g. culture, institutionalism, level of development, infrastructures). The presence of traditional organizational patterns can limit the processes related to creativity and development of products and processes (Erbes et al., 2011). For example, vertical organizations are characterized by the existence of social inequalities, the acceptance of high power distance, and paternalism between non-management and managers (Osland et al., 1999; Pellegrini and Scandura, 2008). The presence of advanced organizational structures in less developed contexts allows professionals to assimilate useful information to expand their own knowledge and experience and to make better decisions.

In sum, the theoretical and empirical background show that the way the firm is organized is critical for internal dynamic knowledge flows. The evidence for Uruguay on this topic is scarce, but there is significant evidence that modern organizational forms positively affect innovation propensity (Barbeito and Bianchi, 2016) and some performance measures (Bello-Pintado, 2011) as observed in other contexts. In the meantime, organizations being more advanced favours the creative and learning capabilities of heterogeneous employees (Bresman and Zellmer-Bruhn, 2013). The fact of being more advanced may allow firms to achieve both radical and incremental innovations.

\section{The Uruguayan innovation System: Stylised facts}

Over the last 30 years, the Uruguayan innovation system has experienced several changes. One of the milestones was the process of rebuilding research capacities and institutional infrastructure, initiated in 1985, after the dictatorship government (1973-1984), which practically destroyed the national research infrastructure. Another crucial change has been the recent public policies that since 2005 have changed the Uruguayan NSI. New instruments and programs have been implemented under a new institutional framework. Moreover, public investment in innovation activities has grown sixfold since 2008. However, the national effort for innovation support and the amount of regular innovation projects are regionally low (Aboal et al., 2014).

The innovation activity rate among industrial firms has not grown since 1985. Since the first innovation survey, around $30 \%$ of firms have self-reported at least one innovation activity - technological or organisational (Bianchi et al., 2015). The Uruguayan NSI shows chronic weakness in innovation activities, agent coordination and knowledge demand from production activities (Arocena and Sutz, 2010). Have been the cycles of the national economy, rather than the innovation strategies of the firms, that explain the industrial dynamics throughout this period (Bittencourt, 2012). 
This does not mean that innovation does not exist in Uruguayan industry. Recent studies show that innovation activities have had a positive impact on labour productivity (Crespi and Zuniga, 2012) and that product innovation has influenced the creation of skilled jobs (Aboal et al., 2011). These recent empirical works used data from different waves of the Uruguayan Innovation Industrial Survey (UIS), but none analysed either workforce diversity or organisational structure.

In a nutshell, innovation in Uruguayan manufacturing can be characterised as an atypical activity; it is mainly concentrated on upgrade activities to enhance competitiveness through capital goods acquisition (Cassoni, 2012). Even though the institutional structure of the NSI has dramatically changed, leveraging the first explicit national STI policy and also the public budget for research and innovation, the traditional manufacturing sector has not been particularly involved in this processes.

In this regard, there are two main features that appear as structural constraints to innovation, related to the particular condition of being small middle income country. First, Uruguay has had chronically low investment, and scale constraints which impose a threshold on the financial amount destined to innovation projects (Aboal et al., 2014). Second, within the Latin American landscape, Uruguay shows a relatively developed innovation system. However, it presents strong coordination lacks, in particular because the traditional and more relevant economic activities of the country -e.g. manufacturing industry- have barely been affected by the recent changes (Berrutti and Bianchi, 2017).

High employment rates characterised the Uruguayan labour market during the period considered in this study. Moreover, the share of low-skilled employment fell in the Uruguayan economy while professional and technical employment grew (Cruces et al., 2017). However, labour supply constraints nevertheless appeared as a potential restriction to the economic growth trend (Perazzo, 2012). The general growth of the workforce's educational level observed during the period may contribute softening the supply of professionally trained work. However, worker mobility between the manufacturing and services sectors reinforce the above-mentioned constraint (Apella and Zunino, 2017).

Considering previous theoretical approaches and existing empirical evidence, we propose the following four hypotheses on the relationship between HED and innovation performance:

H1: There is a positive association between HED and the achievement of both radical and incremental innovation in small developing countries.

H2: HED is more intensely associated with radical than incremental innovations.

H3: The positive association between HED and the achievement of both radical and incremental innovation is positively moderated by the presence of advanced organizational forms.

H4: The positive moderation of advanced organizational forms is higher for the achievement of radical innovations than for incremental innovation. 


\section{EMPIRICAL STRATEGY}

We use panel data from three waves of the Uruguayan Innovation Survey (UIS), which covers 2004-2012. The UIS is an official survey carried out by the National Institute of Statistics and the National Innovation and Research Agency of Uruguay.

The unit of analysis is the industrial firm and the structure of the dataset is an unbalanced panel which only includes firms that were surveyed in at least two waves. Our final database is comprised of 875 observations from 328 firms, where $75 \%$ of the firms were surveyed in all the three waves and $25 \%$ twice.

\subsection{Dependent variable: Innovation performance}

We consider three dummy dependent variables that identify: i) if the firm developed technological innovations in products or processes (tipp), ii) if the firm obtained a radical innovation or not (radical), and iii) if it obtained an incremental innovation or not (incremental).

According to the available information in the UIS database, radical innovation is defined as a product or process that is new for the international market, while an incremental innovation is defined as a product or process that is new for the firm or for the domestic market. Therefore, these are not mutually exclusive categories. However, there are significant differences between the observations of firms that obtained incremental innovation results compared to those that obtained radical ones (Table 1).

It is worth keeping in mind that the sample covers only the firms that conducted innovation activities, whether technological or organizational.

\subsection{Explanatory variable: Workforce horizontal educational diversity}

Measuring diversity is always complex (Stirling, 1998) and the relationship between workforce diversity and innovation performance involves endogeneity problems (Ozgen et al., 2017). To deal with such problems, recent works have used a mix of data from innovation surveys and other administrative sources (Östergaård et al., 2011) or used introduce instrumental variables (Parrotta et al.,

TABLE 1

DISTRIBUTION OF DEPENDENT VARIABLES

\begin{tabular}{|lcc|}
\hline & \% of the sample & $\mathrm{N}$ \\
\hline Technological innovation in products or & 89.49 & 783 \\
processes (TPP) & 86.40 & 756 \\
Incremental innovation TPP & 10.40 & 91 \\
Radical innovation TPP & \\
\hline
\end{tabular}

Source: Authors' calculations based on UIS data. 
2014). However, this type of data is not available for Uruguayan firms. Hence, we measured HED using information from the UIS. The HED variable was calculated using different diversity indices comprised of indicators of educational specialization of the professional employees in the firm.

This methodological choice is in line with previous research. Several studies have pointed out the relevance of the formal education of employees as a knowledge source for a firm's innovation process (Black and Lynch, 2004) and specifically for use as a measure of workforce diversity (Parrotta et al., 2014; Östergaård et al., 2011). In fact, studies for both developed and developing countries usually stress the relevance of the educational level of the workforce as a critical barrier to innovation (Santiago et al. 2017; D'Este et al., 2014).

There are many alternatives to measure diversity using different entropy and diversity indices. The literature specialised on diversity measurement has stressed pros and cons of each index and has emphasised the relevance of using multiple indices to check robustness (Ozgen et al., 2017; Harrison and Klein, 2007; Stirling, 2007).

In our case used three diversity indices to measure HED. First, the Blau's heterogeneity index (1).

$$
\mathrm{Blau}=1-\sum_{i=1}^{k} p_{i}^{2}
$$

where $k$ is the total number of diversity-related characteristics, $i$ is the characteristic of interest and $p_{i}$ is the proportion of individuals with characteristic $i$ among the totality of individuals with $k$ characteristics in the firm. Higher values of the Blau Index indicate higher variety in the attribute of interest, while the relative weight of each characteristic $\mathrm{i}$ is considered as an indicator of balance.

The variable (Blau) $i$ considers $k=10$, taking into account the ten professional backgrounds ( $i$ ) registered by the UIS: 1) Physics and Chemistry, 2) Mathematics and Statistics, 3) Biology, Biochemistry and Biophysics, 4) Medicine, 5) Engineering, 6) Architecture, 7) System Engineering, 8) Agricultural Engineering and Veterinary Medicine, 9) Accounting and Law and 10) Humanities and Social Sciences. The proportion of individuals $\left(p_{i}\right)$ is calculated as the ratio between the number of professionals with each background $i$ over the total number of professionals in the firm's workforce. The proportion of individuals $\left(p_{i}\right)$ is calculated as the ratio of the number of professionals with each background $i$ divided by the total number of professionals in the firm's workforce.

Second, the Simpson Index (2), which follows a similar calculus as the Blau Index but, is less sensitive to potential biases due to cases with only one professional.

$$
\text { Simpson }=1-\left\{\sum_{b=1}^{B} \frac{P_{b i}\left(P_{b i}-1\right)}{L_{i}\left(L_{i}-1\right)}\right\}
$$


Using the same professional attributes as the Blau Index, $B=10: P_{b i}$ is the number of professional employees with background specialization $b(\mathrm{~b}=1,2 \ldots, \mathrm{B})$ and $L_{i}(\mathrm{i}=1, \ldots \mathrm{N})$ is the total number of employees. The Simpson Index measures the likelihood that two randomly selected individuals belong to the same group (same professional background). When all employees share the same attribute, the Simpson Index is equal to 0 , while it is equal to 1 when the share of each attribute in the total workforce is equal.

Finally, we calculated the Shannon-Weaver Index (3), using the same categories of professional education of employees:

$$
S-W=\sum p_{i} * \ln p_{i}
$$

Where $p_{i}$ is the share of employees with professional background $i$. A high value of the $\mathrm{S}-\mathrm{W}$ Index represents a high diversity and equal distribution of the attributes, while lower values represent less diversity.

The distributions of the three indices show that the Simpson Index seems affected by the extreme values. However, both the Blau and the Shannon-Weaver Index show a similar distribution with a high presence of zero value cases. Due to the logarithmic calculus of the S-N Index, it shows a smoother distribution than the Blau Index (Figure1).

A one-period lag of the independent variables was used in the model specification. As usual, it implied losing observations (see final subsample in Table 1), but it allows us to control for problems involving the simultaneity of activities related to innovation results and the HED (Secchi et al., 2016).

It is worth highlighting that lagging explanatory and control variables does not completely mitigate endogeneity problems. As mentioned above, due to the non-availability of administrative records or instrumental variables, we only use data from the UIS, which means that this research is devoted to explaining HED as a determinant of innovation performance in terms of correlation, but it does not claim a causal explanation.

\subsection{Moderating variable: Organizational structure}

We understand organizational structure (advanced) as those organizational practices that leverage communication within the firm, offset hierarchical barriers for knowledge flows and establish incentives for employees to innovate.

To analyse the moderating effects of organizational structure, we use the section of the UIS devoted to work organisation, adapting the classifications previously developed by Camisón and Villar-López (2014) and Lund and Gjerding (1996). Specifically, we create an additive index which counts whether the firm has implemented specific advanced organizational practices: continuous improvement groups; inter-functional working groups; permanent internal communications practices; vertical differentiation (reduction in hierarchical levels); or process certification. 
FIGURE 1

DISTRIBUTION OF HED INDICES

Panel 1a

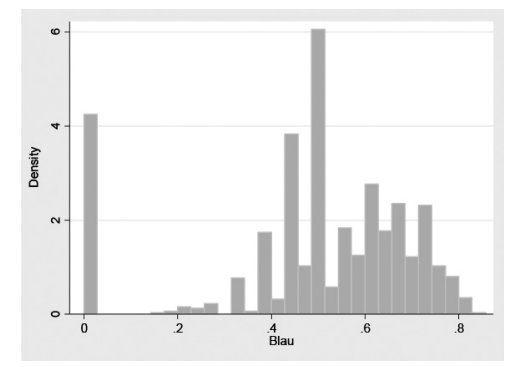

Panel $1 b$

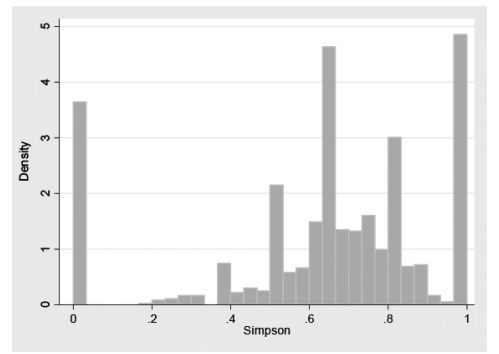

Panel 1c

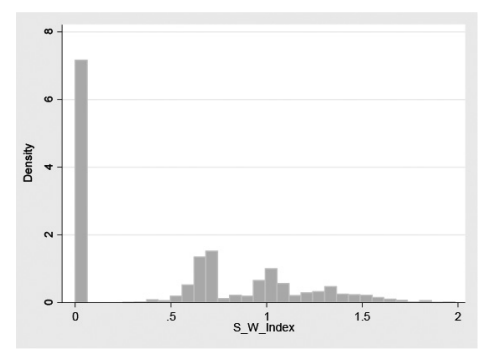

Source: Authors' calculations based on UIS data.

The index on organizational structure, $O S$, captures a positive effect on the variable of interest across its distribution (Smith et al., 2005). The descriptive statistics show that, on average, Uruguayan manufacturing firms with traditional organizational structures have an average index value of 1.832 on a $0-5$ scale (Table 3).

\subsection{Control variables}

We introduce a number of variables to control for the potential effect of HED on innovation performance.

First, as previous research has stressed (Bolli et al., 2018), it is necessary to differentiate the effect of the presence of highly skilled employees from the horizontal diversity among these employees. Hence, we introduce a dummy variable (prof) that measures the presence of at least one professional in the firm's workforce.

Second, in order to control for the effect of innovation activity on innovation outcomes of the firm, we use a dummy variable that takes a value of 1 if the firm has conducted R\&D activities. 
Finally, we use a number of control variables that have been broadly analysed as determinants of innovation performance and should be considered when estimating the effect of WHDE (e.g. Ahuja et al., 2008).

Firm size (logSize) effects on innovation propensity have been discussed since the seminal works of Schumpeter. Also, previous studies about innovation in Latin America stressed that firm size (which tends to be small in the region) can affect access to the minimum financial and human resources needed to conduct technological innovation activities (Chudnovsky et al., 2006). Moreover, the empirical background on innovation in Uruguayan industry shows a positive relationship between the size of the firm and innovation performance (Cassoni, 2012; Bianchi et al., 2015). We measure size as a firm's total number of employees, using a logarithmic transformation to deal with the non-normal distribution of the variable.

Foreign direct investment $(F D I)$ into the firm has been shown to have a positive relationship with innovation propensity in developed economies as well as in countries integrated into global investment flows (Stiebale and Reize, 2011). However, the evidence about the knowledge diffusion effect of FDI in developing countries is far from conclusive (Marín and Sasidharan, 2010). This work highlights the moderating role of internal capabilities and human resources in the relationship between FDI and innovative firm behaviour in developing countries. Hence, when controlling for education levels and organizational structure, we expect a positive relationship between FDI and innovation results. Regarding the dataset restrictions, we measured FDI as a dummy variable which takes positive values if the foreign capital is equal to or greater than $10 \%$ of the total capital of the firm.

The age of the firm (logAge) is measured as the difference between the year of the survey wave and the year when the firm began to operate. To address the non-normal distribution, we use logarithmic transformation. The relationship between the age and the innovation behaviour of a firm is controversial: both theoretical and empirical arguments stress differences by industry and context (Coad et al., 2016). However, there is a basic consensus that firm age negatively affects innovation intensity in high tech industries in developed countries (Balasubramanian and Lee, 2008), while in low tech industries older firms may have more internal assets to conduct technological innovation activities (Thornhill, 2006). Hence, considering the main characteristics of Uruguayan industry, we expect a positive relationship between the age and the innovation performance of the firm.

The export propensity of the firm is measured as its exports as a percentage of total sales of the firm. The relationship between firm export performance and innovation outcomes has been extensively studied. Several works find significant correlation between these variables, stressing that the type of innovation -product or process-can affect export propensity and intensity differently, while exports are positively associated with the innovation performance of the firm (Becker and Egger, 2013). Even though there are heterogeneous results by sector and product, recent empirical works corroborated a positive relationship between 
process innovation and export intensity in Uruguayan industry (Peluffo and Silva, 2016). Hence, we expect a positive effect of export intensity on innovation results.

Finally, in our estimate we control for the firm's sector of activity. We considered seven groups of activity, and each of them is introduced as a dummy variable in the models: a) food, beverages and tobacco; b) textiles, clothing, leather and shoes; c) wood and paper; d) chemical, rubber and minerals; e) metallurgy and transport vehicles; f) machinery and equipment (industrial, office, electrical, communication and medical); and g) others (print and furniture). The relevance of the activity sector as an indicator of market structure and technological characteristics of the firm has been emphasized by many authors (Ahuja et al., 2008). Even though previous empirical studies showed the high inter-sectoral and intra-sectoral heterogeneity, they did not find a significant relationship between innovation and sector of activity in Uruguay.

TABLE 2

NAME AND TYPE OF VARIABLES INCLUDED IN THE ESTIMATIONS

\begin{tabular}{|llccc|}
\hline \multicolumn{1}{|c}{ Variable } & Name & \multicolumn{2}{c|}{ Type } \\
\hline 1. & Technological innovation in & tipp & Dichotomous & Dependent \\
2. & Radical ro processes (TPP) & radical & Dichotomous & Dependent \\
3. Incremental innovation TPP & incremental & Dichotomous & Dependent \\
4. Blau Index & Blau & Continuous & Independent \\
5. Shannon-Weaver Index & S-W & Continuous & Independent \\
6. Simpson Index & Simpson & Continuous & Independent \\
7. Organizational structure index & OS & Additive-Ordinal & Moderating \\
8. Professional employees & Prof & Dummy & Control \\
9. R\&D activities & RD & Dummy & Control \\
10. Firm size (log) & logSize & Continuous & Control \\
11. FDI & FDI & Dichotomous & Control \\
12. Age & logAge & Continuous & Control \\
13. Export intensity (\% of total sales) & export & Continuous & Control \\
14. Dummy of activity sector & & Dichotomous & Control \\
\hline
\end{tabular}

Source: Authors.

\section{ECONOMETRIC MODELS AND ESTIMATION RESULTS}

The correlation matrix between the variables of interest (Table 3) shows some expected results and others that are counterintuitive. First, it shows significant correlations, in particular between the explanatory and the control variables. However, the explanatory variables are not shown to have significant correlation with the dependent ones. On the other hand, the indicator of organizational structure of the firm shows a strong and significant relationship with the dependent variables.

The distribution of the sample mirrors the structure of Uruguayan industry, reflecting the high presence of traditional activity sectors, mainly in food 


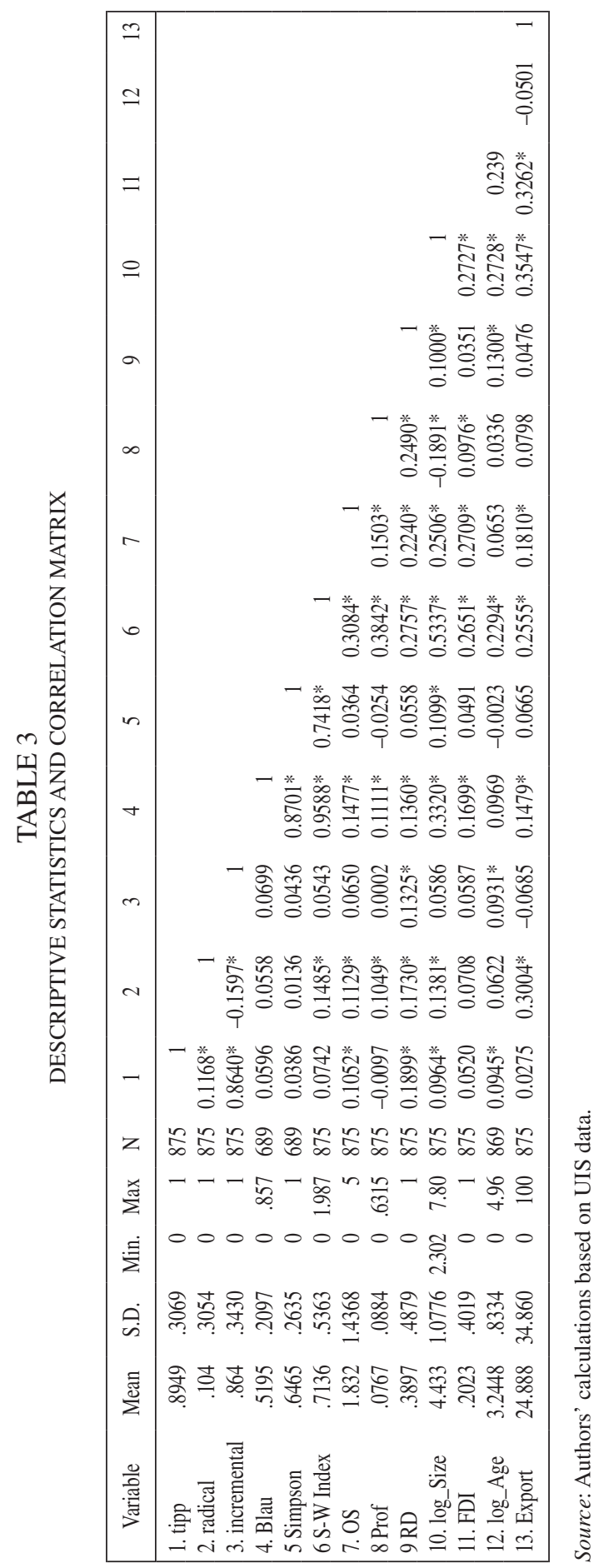




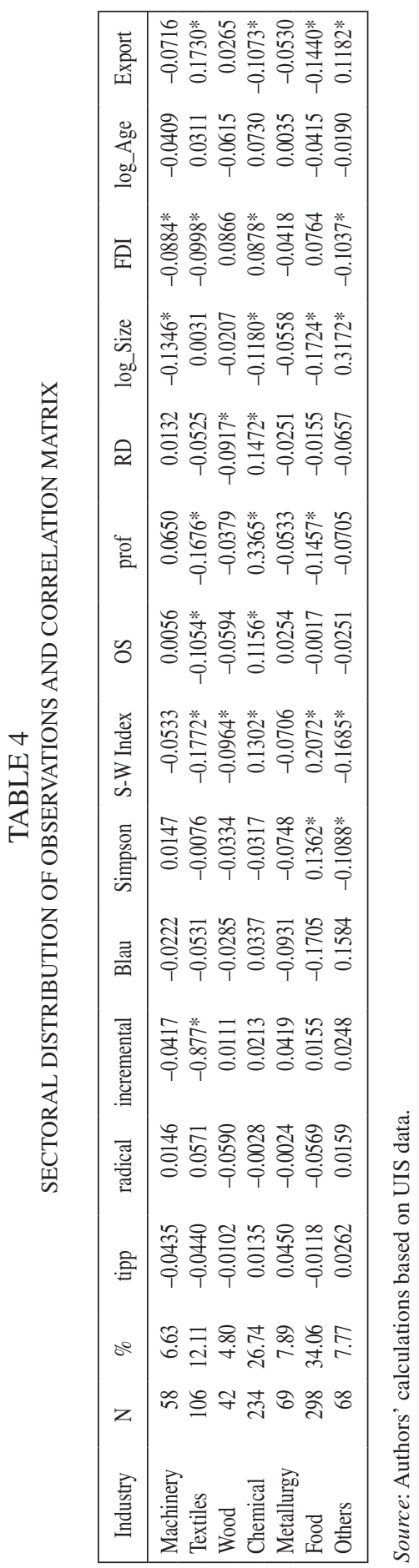


industries. Moreover, there is not a clear correlation between the sector of activity and the variables of interest.

To test hypotheses we used discrete choice panel data models, specifically, by means of logit models with random effects and robust standard errors. We test other specifications, e.g. firm fixed effects, but the absence of variation among the cases discouraged this alternative specification.

The first model, used to test $H 1$ and $H 2$, is specified as:

$$
P\left(y_{i t}=1\right)=\beta_{0}+\beta_{1} \text { Index }_{t-1}+\beta_{2}\left(z_{t}\right)+\varepsilon_{i t}
$$

where $y$ is the dichotomous independent variable observed at time $t ; i$ refers to the type of innovation (tipp, radical or incremental); Index $_{t-1}$ is the independent variable which measures HED through the three indices already mentioned, lagged one period; and $(z)$ is a vector of control variables observed at time $t$. Finally, $\varepsilon$ is the normally distributed error term. We include the square of the independent variables in order to test for the presence of a quadratic distribution.

We checked firm organisational form's moderating effect on the relationship between educational variety and innovation results $(\mathrm{H} 3$ and $\mathrm{H4}$ ) through the following specification:

$$
P\left(y_{i t}=1\right)=\beta_{0}+\beta_{1} \operatorname{Index}_{t-1}+\beta_{2} O S_{t-1}+\beta_{3}\left(O S_{t-1} * \operatorname{Index}_{t-1}\right)+\beta_{4}\left(z_{t}\right)+\varepsilon_{i t}
$$

where all the terms presented in equation (2) remain, while the indicator of advanced organizational structure $(O S)$ is included with a one-period lag, as well as the interaction terms between the independent variables and the moderating one.

All the models were estimated in successive steps by introducing each block of variables in each new estimation (Tables 5-7).

Econometric estimations show robust results. The HED and innovation performance are barely correlated in Uruguayan manufacturing; when a quadratic term is introduced, significance is lost. Therefore, $H 1$ is only partially corroborated while $H 2$ is fully verified. In other words, we identified a positive and significant correlation between HED and innovation performance, when the moderating role of firm organizational structure is tested.

In addition, as tables 4 to 6 show, the moderating effect of organizational structure on the relationship between HED and innovation performance is only significant when radical TPP innovation (technological innovation in products or process) is considered. In other words, $H 3$ and $H 4$ are only partially corroborated.

Lastly, with regard to control variables, the econometric results show the expected positive and significant association between export performance and radical innovation. This result allows us to identify a specific pattern of exportoriented innovation based on radically new products and processes. 
TABLE 5

LOGIT MODEL ESTIMATION. HED MEASURES: BLAU INDEX

\begin{tabular}{|c|c|c|c|c|c|c|c|c|c|c|}
\hline & \multicolumn{3}{|c|}{ TIPP } & \multicolumn{3}{|c|}{ Radical } & \multicolumn{3}{|c|}{ Incremental } \\
\hline & & (1) & (2) & (3) & (4) & (5) & (6) & (7) & (8) & (9) \\
\hline \multirow[t]{3}{*}{ Blau (t-1) } & Coef & 2.216 & 1.380 & 0.465 & -2.216 & -0.543 & -2.460 & 2.942 & $2.004 *$ & 1.715 \\
\hline & SE & (2.439) & (1.079) & (1.113) & (3.553) & (1.693) & (1.832) & $(2.125)$ & (1.107) & (1.154) \\
\hline & Margin & 0.363 & 0.201 & 0.676 & 0.533 & 0.749 & 0.179 & 0.166 & 0.0702 & 0.137 \\
\hline \multirow{3}{*}{$\begin{array}{l}\text { Blau_square } \\
\text { (t-1) }\end{array}$} & Coef & -0.150 & & & 6.637 & & & -2.204 & & \\
\hline & SE & (3.365) & & & (4.133) & & & $(2.845)$ & & \\
\hline & Margin & 0.964 & & & 0.108 & & & 0.439 & & \\
\hline \multirow[t]{3}{*}{ OS $(\mathrm{t}-1)$} & Coef & & 0.0933 & $-3.49 \mathrm{e}-05$ & & -0.576 & $-0.862 * *$ & & 0.193 & 0.208 \\
\hline & SE & & $(0.299)$ & $(0.268)$ & & $(0.369)$ & $(0.416)$ & & $(0.298)$ & $(0.293)$ \\
\hline & Margin & & 0.755 & 1.000 & & 0.119 & 0.0382 & & 0.517 & 0.477 \\
\hline \multirow[t]{3}{*}{ Blau*OS (t-1) } & Coef & & 0.232 & 0.317 & & $1.837 * * *$ & $1.971^{* * * *}$ & & -0.386 & -0.447 \\
\hline & SE & & $(0.553)$ & $(0.539)$ & & $(0.690)$ & $(0.705)$ & & $(0.550)$ & $(0.542)$ \\
\hline & Margin & & 0.674 & 0.556 & & 0.00773 & 0.00518 & & 0.482 & 0.410 \\
\hline \multirow[t]{3}{*}{$\operatorname{Prof}(\mathrm{t}-1)$} & Coef & & & -2.009 & & & 3.260 & & & -0.737 \\
\hline & SE & & & (2.537) & & & (2.249) & & & $(1.971)$ \\
\hline & Margin & & & 0.428 & & & 0.147 & & & 0.708 \\
\hline \multirow[t]{3}{*}{$\mathrm{RD}(\mathrm{t}-1)$} & Coef & & & $1.655^{* * * *}$ & & & $1.143 * *$ & & & 0.564 \\
\hline & SE & & & $(0.628)$ & & & $(0.513)$ & & & $(0.413)$ \\
\hline & Margin & & & 0.00837 & & & 0.0259 & & & 0.172 \\
\hline \multirow[t]{3}{*}{ log_size } & Coef & & & 0.0151 & & & 0.107 & & & -0.0606 \\
\hline & SE & & & $(0.219)$ & & & $(0.256)$ & & & $(0.215)$ \\
\hline & Margin & & & 0.945 & & & 0.675 & & & 0.778 \\
\hline \multirow[t]{3}{*}{ FDI (t-1) } & Coef & & & 0.105 & & & -0.786 & & & 0.373 \\
\hline & SE & & & $(0.461)$ & & & $(0.586)$ & & & $(0.452)$ \\
\hline & Margin & & & 0.819 & & & 0.180 & & & 0.409 \\
\hline \multirow[t]{3}{*}{ log_age } & Coef & & & 0.330 & & & 0.233 & & & 0.388 \\
\hline & SE & & & $(0.249)$ & & & $(0.514)$ & & & $(0.238)$ \\
\hline & Margin & & & 0.185 & & & 0.650 & & & 0.104 \\
\hline \multirow[t]{3}{*}{ Export (t-1) } & Coef & & & -0.000544 & & & $0.0294 * * *$ & & & -0.00688 \\
\hline & SE & & & $(0.00565)$ & & & $(0.00775)$ & & & $(0.00531)$ \\
\hline & Margin & & & 0.923 & & & 0.000146 & & & 0.195 \\
\hline \multirow{3}{*}{ machinery } & Coef & & & -0.997 & & & 0.704 & & & -0.794 \\
\hline & SE & & & $(0.621)$ & & & $(0.704)$ & & & $(0.602)$ \\
\hline & Margin & & & 0.108 & & & 0.317 & & & 0.187 \\
\hline \multirow[t]{3}{*}{ textiles } & Coef & & & -0.245 & & & -0.0261 & & & -0.828 \\
\hline & SE & & & $(0.613)$ & & & $(0.735)$ & & & $(0.557)$ \\
\hline & Margin & & & 0.690 & & & 0.972 & & & 0.137 \\
\hline \multirow[t]{3}{*}{ wood } & Coef & & & -0.565 & & & -0.383 & & & -0.345 \\
\hline & SE & & & $(0.537)$ & & & $(1.335)$ & & & $(0.594)$ \\
\hline & Margin & & & 0.293 & & & 0.774 & & & 0.562 \\
\hline \multirow[t]{3}{*}{ chemical } & Coef & & & -0.342 & & & 0.194 & & & -0.401 \\
\hline & SE & & & $(0.499)$ & & & $(0.617)$ & & & $(0.468)$ \\
\hline & Margin & & & 0.493 & & & 0.754 & & & 0.392 \\
\hline metallurgy & Coef & & & 23.43 & & & 0.490 & & & 0.957 \\
\hline & SE & & & (0) & & & $(0.800)$ & & & $(1.082)$ \\
\hline & Margin & & & & & & 0.541 & & & 0.376 \\
\hline others & Coef & & & -0.906 & & & -22.31 & & & -0.660 \\
\hline & SE & & & $(0.662)$ & & & $(0)$ & & & $(0.643)$ \\
\hline & Margin & & & 0.171 & & & & & & 0.305 \\
\hline Food (omitted) & Coef & & & - & & & & & & \\
\hline Observations & & 469 & 469 & 469 & 469 & 469 & 469 & 469 & 469 & 469 \\
\hline Cases & & 329 & 329 & 329 & 329 & 329 & 329 & 329 & 329 & 329 \\
\hline
\end{tabular}

$* * * \mathrm{p}<0.01, * * \mathrm{p}<0.05, * \mathrm{p}<0.1$. 
TABLE 6

LOGIT MODEL ESTIMATION. HED MEASURES: SIMPSON INDEX

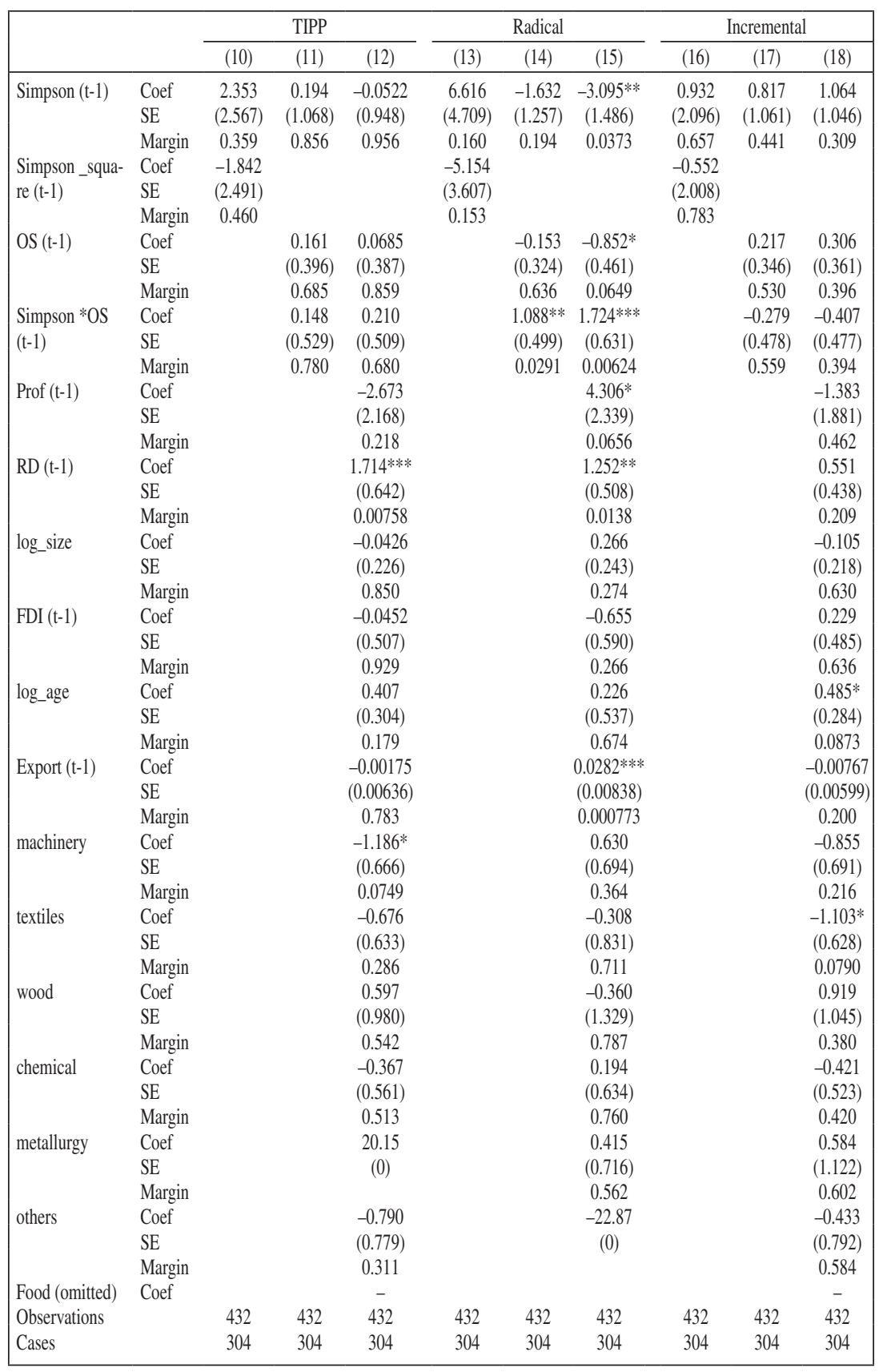

$* * * \mathrm{p}<0.01, * * \mathrm{p}<0.05, * \mathrm{p}<0.1$. 
TABLE 7

LOGIT MODEL ESTIMATION. HED MEASURES: SHANNON-WEAVER INDEX

\begin{tabular}{|c|c|c|c|c|c|c|c|c|c|c|}
\hline & \multicolumn{3}{|c|}{ TIPP } & \multicolumn{3}{|c|}{ Radical } & \multicolumn{3}{|c|}{ Incremental } \\
\hline & & (19) & (20) & (21) & (22) & (23) & (24) & (25) & (26) & (27) \\
\hline \multirow[t]{3}{*}{ S-W (t-1) } & Coef & 1.022 & 0.688 & 0.183 & 1.904 & 0.665 & -0.559 & 0.607 & $0.913^{*}$ & 0.641 \\
\hline & SE & $(0.350)$ & $(0.440)$ & $(0.566)$ & $(0.541)$ & $(0.752)$ & $(0.940)$ & $(0.286)$ & $(0.469)$ & $(0.554)$ \\
\hline & Margin & 0.00350 & 0.119 & 0.746 & 0.0004 & 0.376 & 0.552 & 0.0339 & 0.0517 & 0.247 \\
\hline \multirow{3}{*}{$\begin{array}{l}\text { S-W_square } \\
(\mathrm{t}-1)\end{array}$} & Coef & -0.003 & & & -0.046 & & & -0.093 & & \\
\hline & SE & $(0.550)$ & & & $(0.340)$ & & & $(0.480)$ & & \\
\hline & Margin & 0.00060 & & & 0.0073 & & & 0.00210 & & \\
\hline \multirow[t]{3}{*}{ OS $(t-1)$} & Coef & & 0.121 & 0.0577 & & -0.0066 & -0.284 & & 0.168 & 0.163 \\
\hline & SE & & $(0.205)$ & $(0.203)$ & & $(0.273)$ & $(0.322)$ & & $(0.197)$ & $(0.194)$ \\
\hline & Margin & & 0.555 & 0.776 & & 0.980 & 0.377 & & 0.393 & 0.401 \\
\hline \multirow{3}{*}{$\mathrm{S}-\mathrm{W} * \mathrm{OS}(\mathrm{t}-1)$} & Coef & & 0.0941 & 0.103 & & $0.462 *$ & $0.565^{*}$ & & -0.195 & -0.220 \\
\hline & SE & & $(0.232)$ & $(0.247)$ & & $(0.269)$ & $(0.291)$ & & $(0.216)$ & $(0.215)$ \\
\hline & Margin & & 0.685 & 0.678 & & 0.0865 & 0.0526 & & 0.367 & 0.306 \\
\hline \multirow[t]{3}{*}{$\operatorname{Prof}(\mathrm{t}-1)$} & Coef & & & -1.458 & & & 3.413 & & & -0.449 \\
\hline & SE & & & $(2.478)$ & & & (2.339) & & & (1.911) \\
\hline & Margin & & & 0.556 & & & 0.144 & & & 0.814 \\
\hline \multirow[t]{3}{*}{$\mathrm{RD}(\mathrm{t}-1)$} & Coef & & & $1.718^{* * *}$ & & & $1.103 * *$ & & & $0.649 *$ \\
\hline & SE & & & $(0.610)$ & & & $(0.504)$ & & & $(0.392)$ \\
\hline & Margin & & & 0.00484 & & & 0.0285 & & & 0.0983 \\
\hline \multirow[t]{3}{*}{ log_size } & Coef & & & 0.180 & & & 0.0839 & & & 0.0852 \\
\hline & SE & & & $(0.212)$ & & & $(0.278)$ & & & $(0.207)$ \\
\hline & Margin & & & 0.395 & & & 0.763 & & & 0.680 \\
\hline \multirow{3}{*}{ FDI $(\mathrm{t}-1)$} & Coef & & & 0.149 & & & -0.734 & & & 0.384 \\
\hline & SE & & & $(0.446)$ & & & $(0.581)$ & & & $(0.425)$ \\
\hline & Margin & & & 0.739 & & & 0.206 & & & 0.367 \\
\hline \multirow[t]{3}{*}{ log_age } & Coef & & & 0.202 & & & 0.292 & & & 0.237 \\
\hline & SE & & & $(0.216)$ & & & $(0.516)$ & & & $(0.207)$ \\
\hline & Margin & & & 0.350 & & & 0.571 & & & 0.252 \\
\hline \multirow[t]{3}{*}{ Export (t-1) } & Coef & & & -0.00267 & & & $0.0290 * * *$ & & & $-0.00789 *$ \\
\hline & SE & & & $(0.00507)$ & & & $(0.00736)$ & & & $(0.00462)$ \\
\hline & Margin & & & 0.598 & & & $8.10 \mathrm{e}-05$ & & & 0.0877 \\
\hline \multirow{3}{*}{ machinery } & Coef & & & $-0.937 *$ & & & 0.670 & & & -0.772 \\
\hline & SE & & & $(0.547)$ & & & $(0.707)$ & & & $(0.513)$ \\
\hline & Margin & & & 0.0868 & & & 0.343 & & & 0.132 \\
\hline \multirow[t]{3}{*}{ textiles } & Coef & & & -0.251 & & & -0.139 & & & -0.569 \\
\hline & SE & & & $(0.471)$ & & & $(0.763)$ & & & $(0.457)$ \\
\hline & Margin & & & 0.594 & & & 0.855 & & & 0.213 \\
\hline \multirow[t]{3}{*}{ wood } & Coef & & & -0.197 & & & -0.330 & & & -0.0680 \\
\hline & SE & & & $(0.555)$ & & & $(1.361)$ & & & $(0.563)$ \\
\hline & Margin & & & 0.723 & & & 0.808 & & & 0.904 \\
\hline \multirow[t]{3}{*}{ chemical } & Coef & & & -0.154 & & & 0.142 & & & -0.229 \\
\hline & SE & & & $(0.457)$ & & & $(0.625)$ & & & $(0.421)$ \\
\hline & Margin & & & 0.737 & & & 0.821 & & & 0.587 \\
\hline metallurgy & Coef & & & 22.93 & & & 0.468 & & & 1.483 \\
\hline & SE & & & $(0)$ & & & $(0.801)$ & & & $(1.094)$ \\
\hline & Margin & & & & & & 0.559 & & & 0.175 \\
\hline others & Coef & & & -0.633 & & & -22.92 & & & -0.509 \\
\hline & SE & & & $(0.622)$ & & & $(0)$ & & & $(0.584)$ \\
\hline & Margin & & & 0.309 & & & & & & 0.383 \\
\hline Food (omitted) & Coef & & & & & & & & & \\
\hline Observations & & 536 & 536 & 536 & 536 & 536 & 536 & 536 & 536 & 536 \\
\hline Cases & & 386 & 386 & 386 & 386 & 386 & 386 & 386 & 386 & 386 \\
\hline
\end{tabular}

$* * * \mathrm{p}<0.01, * * \mathrm{p}<0.05, * \mathrm{p}<0.1$. 


\section{DiscuSSION AND CONCLUSIONS}

This paper constitutes a relevant contribution to understanding the innovation dynamic in small developing countries, by focusing on the relationship between workforce educational diversity and innovation performance. In Uruguay, the lack of a highly qualified workforce has been stressed as one of the main restrictions to development of innovation processes (Bianchi et al., 2011). Results show the expected process of creating absorptive capacities (Cohen and Levinthal, 1990). Firms engaging in $\mathrm{R} \& \mathrm{D}$ activities show a positive and significant correlation between these activities and innovation performance in all the estimates. However, it is particularly interesting that when firms achieve radical innovation, there is a positive correlation between HED and advanced organizational structure. Therefore, firms that innovate internally also offer organizational channels to benefit as much as possible from educational diversity.

Overall, the most relevant result obtained appears related to the moderating role of modern organizational forms on the relationship between HED and innovation performance. As tables 4 to 6 show, the moderating effect is only significant when radical TPP innovation is considered. Therefore, $H 3$ and $H 4$ are only partially corroborated.

In addition, the econometric results show a positive and significant association between export performance and radical innovation. This result allows us to identify a specific pattern of export-oriented innovation based on radically new products and processes.

The presence of both breadth and variety of professional profiles constitutes a rich knowledge and creative base for innovation success of firms (Baldwin and Clark, 2000). Moreover, the potential negative effects of high HED already observed in developed countries (Horwitz, 2005) is not corroborated for Uruguay.

In addition, we observe that the organizational structure of firms is very important to explain the achievement of radical innovations. This result indicates that the more innovative companies usually adopt advanced forms of work organization such as reduced hierarchical levels, inter-functional working groups and/or internal communication practices. We also observed that these organizational practices enhance the positive association between diversity in education and performance in radical innovation. This result points to a need to suggest considering the adoption of new organizational forms to improve performance among Uruguayan manufacturing firms; these forms have been suggested to be positively associated with the adoption of technological innovations (Camisón and Villar-López, 2014).

It should be noted that this paper has several limitations that should be addressed in further research. First, our empirical strategy has been focusing only on analysis of HED and innovation performance. Other diversity dimensions could be explored in order to build upon the findings in this paper related to a process of developing absorptive capacities. Moreover, the positive and significant correlation between export intensity and radical innovation may be indicative of how the firm responds to participating in international markets 
with strong competition requirements, which, in turn, are correlated with higher HED and better innovation performance. The strong association between radical innovation and export performance is an expected result for the manufacturing industry of a small developing country. However, the link between innovation performance and product specialization has received little attention from micro level studies. Also, the relationship between workforce diversity and innovation performance may be associated with the innovation strategy of the firm (Bogers et al., 2018). Hence, further study of the workforce diversity -both horizontal and vertical-and the degree of openness of the firm's innovation strategy seems necessary to improve the understanding of workforce diversity effects. This is particularly important in relation to the important debate surrounding skills, innovation and employment, both worldwide and in Latin America (Vivarelli, 2014; Grazzi and Pietrobielli, 2016).

Finally, the results confirm the particular feature of Uruguayan industry where there does not appear to be an identifiable sectoral pattern associated with innovation performance. Hence, in sum, a public effort to leverage innovation performance should promote an increase in professional jobs throughout industry as a key element to increase the share of firms achieving innovations.

To conduct this research agenda, new information and multisource databases are necessary. The identification strategy of the HED effects on innovation performance is only based on the test of significant correlation among the dependent variable and lagged explicative variables. Further lines of research will require an empirical strategy that addresses endogeneity biases in the relationship between workforce diversity and innovation performance, and also auto-correlations of workforce diversity, over time.

\section{REFERENCES}

Aboal, D., P. Angelelli, G. Crespi, A. López and M. Vairo (2014). "Innovación en Uruguay". IADB Research Report. Montevideo.

Aboal, D., P. Garda, B. Lanzilotta and M. Perera (2011). "Innovation, Firm Size and Employment Generation in Uruguay: The Microeconometric Evidence". BID. CINVE, Montevideo.

Ahuja, G., C. Morris and V. Tandon (2008). "Moving beyond Schumpeter: Management Research on the Determinants of Technological Innovation". The Academy of Management Annals, 2, 1-98.

Apella, I. and G. Zunino (2017). "Cambio Tecnológico y Mercado de Trabajo en Argentina y Uruguay. Un Análisis desde el Enfoque de Tareas". Washington, D.C.: World Bank Group.

Arocena, R. and J. Sutz (2010). "Weak Knowledge Demand in the South: Learning Divides and Innovation Policies". Science and Public Policy, 37, 571-82.

Balasubramanian, N. and J. Lee (2008). "Firm Age and Innovation". Industrial and Corporate Change, 17, 1019-1047. 
Baldwin, C. and K. Clark (2000). Design Rules: The Power of Modularity. Cambridge, MA: MIT Press.

Bantel, K. and S. Jackson (1989). “Top Management and Innovations in Banking: Does the Composition of the Top Team Make a Difference?" Strategic Management Journal, 10, 107-124.

Barbeito, F. and C. Bianchi (2016). "La Organización del Trabajo Como Determinante del Comportamiento Innovador de las Empresas: Una Aproximación Empírica Mediante Análisis de Datos de Panel”. VI Jornadas Académicas FCEA-UDELAR. Montevideo.

Becker, S. and P. Egger (2013). "Endogenous Product Versus Process Innovation and a Firm's Propensity to Export". Empirical Economics, 44, 329-354.

Bell, S., Villado, A. Lukasik, M. Belau, L. and A. Briggs (2011). "Getting Specific about Demographic Diversity Variable and Team Performance Relationships: A Meta-analysis". Journal of Management, 37, 709-743.

Bello-Pintado, A. (ed.) (2011). Reto de la Innovación en la Empresa Industrial: La Experiencia Uruguaya. Un Largo Camino Hacia la Competitividad. Buenos Aires: Granica.

Berliant, M. and M. Fujita (2011). "The Dynamics of Knowledge Diversity and Economic Growth". Southern Economic Journal, 77, 856-884.

Berrutti, F. and C. Bianchi (2017). "Assessing the Effect of Public Funding on Private Innovation Investment in Uruguay". DT. 04/2017. IECON, FCEA, UDELAR, Uruguay.

Bianchi, C., Lezama, G. and A. Peluffo (2015). "Determinantes de la Innovación en la Industria Uruguaya 1998-2009”. DT 07/2015. IECON, FCEA, UDELAR, Uruguay.

Bianchi, C., Gras, N. and J. Sutz (2011). "Make, Buy and Cooperate in Innovation: Evidence from Uruguayan Manufacturing Surveys and Other Innovation Studies", in: CEPAL-IDRC National innovation surveys in Latin America: Empirical evidence and policy implications. Santiago de Chile: CEPAL.

Bittencourt, G. (2012). "IV Encuesta de Actividades de Innovación en la Industria Uruguaya (2007-2009)". ANII, Montevideo.

Black, S. and L. Lynch (2004). "What's Driving the New Economy? The Benefits of Workplace Innovation". The Economic Journal, 114, 97-116.

Bloom, N. and J. Van Reenen (2010). "Why Do Management Practices Differ across Firms and Countries?" Journal of Economic Perspectives, 24(1), 203-24.

Bogers, M., N. Foss and J. Lyngsie (2018). "The "Human Side" of Open Innovation: The Role of Employee Diversity in Firm-level Openness". Research Policy, 47(1), 218-231.

Bolli, T., U. Renold and M. Wörter (2018). "Vertical Educational Diversity and Innovation Performance". Economics of Innovation and New Technology, 27(2), 107-131.

Bresman, H. and M. Zellmer-Bruhn (2013). "The Structural Context of Team Learning: Effects of Organizational and Team Structure on Internal and External Learning”. Organization Science, 24, 1120-1139. 
Camisón, C. and A. Villar-López (2014) "Organizational Innovation as an Enabler of Technological Innovation Capabilities and Firm Performance". Journal of Business Research, 67, 2891-2902.

Camisón, C. and B. Forés (2010). "Knowledge Absorptive Capacity: New Insights for its Conceptualization and Measurement". Journal of Business Research, 63, 707-715.

Cassoni, A. (2012). "The Innovative Behaviour of Uruguayan Firms - Stylized Facts Revisited". DI No 82, Universidad ORT, Uruguay.

Choi, J., S. Sung and Z. Zhang (2016). "Workforce Diversity in Manufacturing Companies and Organizational Performance: The Role of Status-relatedness and Internal Processes". The International Journal of Human Resource Management, 1-24.

Chudnovsky, D., A. López and G. Pupato (2006). "Innovation and Productivity in Developing Countries: A Study of Argentine Manufacturing Firms' Behavior (1992-2001)". Research Policy, 35, 266-288.

Cohen, W. and D. Levinthal (1990). "Absorptive Capacity - A New Perspective on Learning and Innovation”. Administrative Science Quarterly, 35, 128-152.

Coad, A., A. Segarra and M. Teruel (2016). "Innovation and Firm Growth: Does Firm Age Play A Role?" Research Policy, 45, 387-400.

Crespi, G. and P. Zúñiga (2012). "Innovation and Productivity: Evidence from Six Latin American Countries". World Development, 40(2), 273-290.

Cruces, G., G. Fields, D. Jaume and M. Viollaz (2017). Growth, Employment, and Poverty in Latin America . Oxford University Press.

Dahlin, K., L. Weingart and P. Hinds (2005). "Team Diversity and Information Use". Academy of Management Journal, 48, 1107-1123.

De Carolis, D. and D. Deeds (1999). "The Impact of Stocks and Flows of Organizational Knowledge on Firm Performance: An Empirical Investigation of the Biotechnology Industry". Strategic Management Journal, 20, 953-968.

D'Este, P., F. Rentocchini and J. Vega-Jurado (2014). "The Role of Human Capital in Lowering the Barriers to Engaging in Innovation: Evidence from the Spanish Innovation Survey". Industry and Innovation, 21, 1-19.

De Winne, S. and L. Sels (2010). "Interrelationships between Human Capital, HRM and Innovation in Belgian Start-ups Aiming at an Innovation Strategy". The International Journal of Human Resource Management, 21, 1863-1883.

Díaz-García, C., A. González-Moreno and F. Sáez-Martínez (2013). “Gender Diversity within R\&D Teams: Its Impact on Radicalness of Innovation". Innovation, 15, 149-160.

Duryea, S., J. Navarro and A. Verdisco (2008). "Learning about Education Quality and Perceptions", in: IADB, Beyond facts: Understanding Quality of Life. Washington, DC: Inter-American Development Bank.

Ely, R. and D. Thomas (2001). "Cultural Diversity at Work: The Effects of Diversity Perspectives on Work Group Processes and Outcomes". Administrative Science Quarterly, 46, 229-273. 
Erbes, A., S. Roitter and M. Delfini (2011). “Organización del Trabajo e Innovación: Un Estudio Comparativo entre Ramas Productivas Argentinas”. Economía: Teoría y Práctica, 34, 101-132.

Faems, D. and A. Subramanian (2013). "R\&D Manpower and Technological Performance: The Impact of Demographic and Task-related Diversity". Research Policy, 42, 1624-1633.

García-Martínez, M., F. Zouaghi and T. García-Marco (2017). "Diversity is Strategy: The Effect of R\&D Team Diversity on Innovative Performance". $R \& D$ Management, 47, 311-329.

Goedhuys, M. and R. Veugelers (2012). "Innovation Strategies, Process and Product Innovations and Growth: Firm-level Evidence from Brazil". Structural Change and Economic Dynamics, 23, 516-529.

Grant, R. (1996) "Toward a Knowledge-based Theory of the Firm". Strategic Management Journal, 17, 109-122.

Grazzi, M. and C. Pietrobelli (eds.) (2016). Firm Innovation and Productivity in Latin America and the Caribbean. New York: Palgrave.

Harrison, D. and K. Klein (2007). "What's the Difference? Diversity Constructs as Separation, Variety, or Disparity in Organizations". The Academy of Management Review, 32, 1199-1228.

Horwitz, S. and I. Horwitz (2007). "The Effects of Team Diversity on Team Outcomes: A Meta-analytic Review of Team Demography". Journal of Management, 33, 987-1015.

Horwitz, S. (2005). "The Compositional Impact of Team Diversity on Performance: Theoretical Considerations". Human Resource Development Review, 4, 219-245.

Katz, B. and N. Du Preez (2008). "The Role of Knowledge Management in Supporting a Radical Innovation Project”, pp. 331-345 in: A. Bernard and S. Tichkiewitch (eds.). Methods and Tools for Effective Knowledge Life-Cycle-Management. Berlin Heidelberg: Springer.

Laursen, K., V. Mahnke and P. Vejrup-Hansen (2005). "Do Differences Make a Difference? The Impact of Human Capital Diversity, Experience and Compensation on Firm Performance in Engineering”. Druid Working Paper No. 05-04.

Leiponen, A. (2005). "Core Complementarities of the Corporation: Organization of an Innovating Firm”. Managerial and Decision Economics, 26, 351-365.

Li, C. (2014). "Top Management Team Diversity in Fostering Organizational Ambidexterity: Examining TMT Integration Mechanisms". Innovation, 16, 303-322.

Lund, R. and A. Gjerding (1996). "The Flexible Company. Innovation, Work Organisation and Human Resource Management". Druid Working Paper No. 96-17.

Marín, A. and S. Sasidharan (2010). "Heterogeneous MNC Subsidiaries and Technological Spillovers: Explaining Positive and Negative Effects in India". Research Policy, 39, 1227-1241. 
Muller, E. and A. Zenker (2001). "Business Services as Actors of Knowledge

Transformation: The Role of KIBS in Regional and National Innovation Systems". Research Policy, 30, 1501-1516.

Osland, J., S. De Franco and A. Osland (1999). "Organizational Implications of Latin American Culture: Lessons for the Expatriate Manager”. Journal of Management Inquiry, 8, 219-234.

Östergaård, C., B. Timmermans and K. Kristinsson (2011). "Does a Different View Create Something New? The Effect of Employee Diversity on Innovation". Research Policy, 40, 500-509.

Ozgen, C., P. Nijkamp and J. Poot (2017). “The Elusive Effects of Workplace Diversity on Innovation". Papers in Regional Science, 96(S1).

Pagés, C. (2010). The Age of Productivity: Transforming Economies from the Bottom U. Washington D. C.: Inter-American Development Bank.

Parrotta, P., D. Pozzoli and M. Pytlikova (2014). "The Nexus between Labour Diversity and Firm's Innovation”. Journal of Population Economics, 27, 303-364.

Pelled, L. (1996). "Demographic Diversity, Conflict, and Work Group Outcomes: An Intervening Process Theory". Organization Science, 7(6), 615-631. Pellegrini, E. and T. Scandura (2008). "Paternalistic Leadership: A Review and Agenda for Future Research". Journal of Management, 34, 566-593.

Peluffo, A. and E. Silva (2016). "New Stuff or Better Ways: What Matters to Survive International Markets?” Jornadas de Economía. BCU, Montevideo.

Perazzo, I. (2012). "El Mercado Laboral Uruguayo en la Última Década". DT 01/2012. IECON, FCEA, UDELAR, Uruguay.

Pfeifer, C. and J. Wagner (2014). "Is Innovative Firm Behavior Correlated with Age and Gender Composition of the Workforce? Evidence from a New Type of Data for German Enterprises". Journal for Labour Market Research, 47, 223-231.

Ruiz-Mejías, K. and R. Corrales-Mejías (2015a). "Impacto de la Diversidad y la Participación de los Trabajadores sobre la Innovación de las Empresas: Un Modelo de Regresión en Dos Etapas para el Sector Servicios”. Revista de Política Económica para el Desarrollo Sostenible, 1, 1-22.

Ruiz-Mejías, K. and R. Corrales-Mejías (2015b). “The Impact of Employee Diversity and Participation on Innovation: A Two-Step Regression Model for the Costa Rican Industrial Sector". 13th GLOBELICS International Conference; Havana.

Santiago, F., C. De Fuentes and N. Gras (2017). "What Hinders Innovation Performance of Services and Manufacturing Firms in Mexico?" Economics of Innovation and New Technology, 26, 247-268.

Sapprasert, K. and T. Clausen (2012). "Organizational Innovation and its Effects". Industrial and Corporate Change, 21, 1283-1305.

Schneider, L., J. Günther and B. Brandenburg (2010). "Innovation and Skills from a Sectoral Perspective: A Linked Employer-employee Analysis". Economics of Innovation and New Technology, 19(2), 185-202. 
Schneider, S. and G. Northcraft (1999). “Three Social Dilemmas of Workforce Diversity in Organizations: A Social Identity Perspective”. Human Relations, 52, 1445-1467.

Secchi, A., F. Tamagni and C. Tomas (2016). "Financial Constraints and Firm Exports: Accounting for Heterogeneity, Self-selection and Endogeneity". Industrial and Corporate Change, 25, 813-827.

Shore, L., G. Chung-Herrera, M. Dean, H. Ehrhart, I. Jung, A. Randel and G. Singh (2009). "Diversity in Organizations: Where Are We Now and Where Are We Going?” Human Resource Management Review, 19, 117-133.

Smith, K., C. Collins and K. Clark (2005) "Existing Knowledge, Knowledge Creation Capability, and the Rate of New Product Introduction in Hightechnology Firms". Academy of Management Journal, 48, 346-357.

Stiebale, J. and F. Reize (2011). "The Impact of FDI through Mergers and Acquisitions on Innovation in Target Firms". International Journal of Industrial Organization, 29, 155-167.

Stirling, A. (2007). "A General Framework for Analysing Diversity in Science, Technology and Society". Journal of the Royal Society Interface, 4(15), 707-719.

Stirling, A. (1998). "On the Economics and Analysis of Diversity". Science Policy Research Unit (SPRU), Electronic Working Paper Series, 28, 1-156.

Subramanian, A., Y. Choi, S. Lee and C. Hang (2016). "Linking Technological and Educational Level Diversities to Innovation Performance". The Journal of Technology Transfer, 41(2), 182-204.

Sutz, J. (2012). "Measuring Innovation in Developing Countries: Some Suggestions to Achieve More Accurate and Useful Indicators". International Journal of Technological Learning, Innovation and Development, 5, 40-57.

Thornhill, S. (2006). "Knowledge, Innovation and Firm Performance in High-and Low-technology Regimes”. Journal of Business Venturing, 21, 687-703.

van Knippenberg, D., C. De Dreu and A. Homan (2004). "Work Group Diversity and Group Performance: An Integrative Model and Research Agenda". Journal of Applied Psychology, 89, 1008-1022.

Vivarelli, M. (2014). "Innovation, Employment and Skills in Advanced and Developing Countries: A Survey of Economic Literature". Journal of Economic Issues, 48(1), 123-154.

Wernerfelt, B. (1984). “A Resource-based View of the Firm”. Strategic Management Journal, 5(2):171-180.

Yang, Y. and A. Konrad (2011). "Understanding Diversity Management Practices: Implications of Institutional Theory and Resource-based Theory". Group \& Organization Management, 36, 6-38.

Zahra, S. and G. George (2002). "Absorptive Capacity: A Review, Reconceptualization, and Extension”. Academy of Management Review, 27, 185-203.

Zhou, K. and C. Li (2012). "How Knowledge Affects Radical Innovation: Knowledge Base, Market Knowledge Acquisition, and Internal Knowledge Sharing". Strategic Management Journal, 33, 1090-1102. 
